\title{
ANALISIS NILAI MORAL DALAM NOVEL SURAT KECIL UNTUK TUHAN KARYA AGNES DAVONAR
}

\author{
Cholastina Tampubolon ${ }^{1}$, Hendry Baginta ${ }^{2}$, Annisa $^{3}$ \\ Universitas Prima Indonesia ${ }^{1}$, Universitas Prima Indonesia ${ }^{2}$, Universitas Prima Indonesia ${ }^{3}$ \\ Pos-el: tampusayu05101998@gmail.com ${ }^{1}$, hendryramban@gmail.com ${ }^{2}$, anni83sah@gmail.com
}

\begin{abstract}
ABSTRAK
Tujuan Penelitian ini untuk mengetahui wujud dan bentuk penyampaian nilai moral yang terkandung dalam novel Surat Kecil Untuk Tuhan karya Agnes Davonar dalam kehidupan sehari-hari. Pendekatan penelitian yang digunakan adalah pendekatan kualitatif. Hasil penelitian ini hanya mengetahui wujud dan bentuk penyampaian nilai moral yang terkandung dalam novel Surat Kecil Untuk Tuhan karya Agnes Davonar. Dalam Penelitian ini, Sumber data yang digunakan dalam penelitian ini adalah novel Surat Kecil Untuk Tuhan karya Agnes Davonar yang memiliki tebal 258 halaman. Teknik pengumpulan data dalam penelitian ini menggunakan study naskah (analaysis content). Hasil penelitian menunjukan bahwa novel Surat Kecil Untuk Tuhan karya Agnes Davonar memiliki banyak wujud nilai moral yang bisa dijadikan sebagai contoh kepada penikmat karya sastra dalam bertingkahlaku di kehidupan sehari-hari.
\end{abstract}

Kata Kunci: Nilai Moral, Novel.

\section{ABSTRACT}

The purpose of this research is to study the forms and forms of conveying moral values contained in the novel Little Letter to God by Agnes Davonar in daily life. The research suggestions used are qualitative suggestions. The results of this study only study the forms and forms of delivery of mora values; contained in the novel Letters to the Lord by Agnes Davonar. In this study, the data source used in this study is the Small Letter to God novel by Agnes Davonar which has a thickness of 258 pages. Data collection techniques in this study used research texts (analaysis content). The results of the research show that Agnes Davonar's Little Letter to God has many forms of moral values that can be made as examples for literary connoisseurs in acting in everyday life.

Keywords: Moral Values, Novel.

\section{PENDAHULUAN}

Karya sastra merupakan wadah untuk menyampaikan pemikiran pengarang kepada pembaca atau penikmat karya sastra yang bersifat imajinatif, estetik dan dijadikan sebagai hiburan sekaligus memberi manfaat dalam kehidupan penikmat karya sastra. Salah satu bentuk karya sastra yang bersifat imajinatif adalah novel atau karya sastra yang mengandung nilai-nilai tertentu didalamnya. Sehingga nilai-nilai tersebut memiliki manfaat dalam kehidupan sehari-hari misalnya nilai moral.

Menurut Shaffer dalam oleh Asri Budiningsih (2004: 24) moral dapat diartikan sebagai kaidah norma dan pranata yang mampu mengatur perilaku individu dalam menjalani suatu hubungan dengan masyarakat. Menurut Nurgiyantoro (2013:441-445), wujud dari penyampaian moral berkaitan dengan hal-hal sebagai berikut: (a) Hubungan manusia dengan diri sendiri (b) Hubungan manusia dengan manusia 
lain dalam lingkup sosial dan lingkungan alam (c) Hubungan manusia dengan Tuhan.

Moral memiliki peranan penting bagi setiap individu. Dengan adanya moral maka dapat membentuk prilaku individu yang beretika dan sopan santun sesuai dengan chiri khas penduduk negara indonesia. Novel Surat Kecil Untuk Tuhan karya Agnes Davonar memiliki nilai moral yang dapat dijadikan sebagai contoh kepada penikmat karya sastra dalam bertingkah laku di kehidupannya sehari-hari.

Novel yang bejudul Surat Kecil Untuk Tuhan yang ditulis oleh Agnes Davonar dan diterbitkan pertama kali pada tahun 2008 namun dicetak kembali pada tahun 2015 ini menceritakan perjuangan hidup seorang anak gadis remaja yang menderita penyakit kanker jaringan lunak pertama di Indonesia. Novel ini memiliki tokoh utama wanita yang bernama Keke, seorang gadis remaja cantik, pintar dan mantan artis penyanyi cilik berusia 13 tahun.

Melihat kenyataan ini peneliti berinisiatif untuk menganalisis nilai moral dalam novel Surat Kecil Untuk Tuhan Karya Agnes Davonar karena novel tersebut memiliki nilai moral yang dapat dijadikan sebagai contoh kepada penikmat karya sastra baik dalam bertingkah laku di kehidupannya seharihari.

Berdasarkan latar belakang tersebut, maka identifikasi masalah yang dirumuskan dalam penelitian ini yaitu kurangnya kesadaran penikmat karya sastra dalam memanfatkan nilai moral yang terkandung dalam novel Surat Kecil untuk Tuhan karya Agnes Davonar untuk direalisasikan pada kehidupan sehari-hari.

Dalam penelitian ini batasan masalahnya, yaitu nilai moral dalam novel Surat Kecil Untuk Tuhan karya Agnes Davonar.
Berdasarkan batasan masalah tersebut, maka yang menjadi rumusan masalah yaitu Bagaimana wujud dan bentuk penyampaian nilai moral yang terdapat di dalam Surat Kecil Untuk Tuhan karya Agnes Davonar dalam kehidupan sehari-hari?

Berdasarkan rumusan masalah diatas maka peneliti merumuskan tujuan Penelitian ini adalah untuk mengetahui wujud dan bentuk penyampaian nilai moral yang terkandung dalam novel Surat Kecil Untuk Tuhan karya Agnes Davonar dalam kehidupan sehari-hari.

Adapun manfaat dari penelitian yang akan dilakukan ialah dapat dipergunakan untuk memahami ajaran nilai moral dan memberikan pengaruh yang terkandung dalam novel Surat Kecil Untuk Tuhan karya Agnes Davonar.

\section{METODE PENELITIAN}

Metode yang digunakan untuk menganalisis nilai moral dalam novel Surat Kecil Untuk Tuhan Karya Agnes Davonar ini adalah metode kualitatif. Menurut Sugiyono (2009:15) metode penelitian kualitatif adalah penelitian yang digunakan untuk menyelidiki, menemukan, menggambarkan, dan menjelaskan kualitas atau keistimewaan dari pengaruh sosial yang tidak dapat dijelaskan, diukur atau digambarkan melalui pendekatan kualitatif.

Teknik pengumpulan data yang dapat digunakan dalam penelitian ini menggunakan studi naskah (analysis content). Hasil penelitian menunjukkan bahwa jumlah keseluruhan data dari nilai moral dalam novel Surat Kecil Untuk Tuhan Karya Agnes Davonar sebanyak 3 data dimana Nilai Moral Hubungan Manusia dengan Diri Sendiri, Nilai Moral Hubungan Manusia dengan Manusia Lain dalam Lingkup Sosial dan lingkungan alam, Nilai Moral Hubungan Manusia dengan Tuhannya. 


\section{HASIL DAN PEMBAHASAN}

Dari hasil penelitian dan pembahasan yang dilakukan secara garis besar mengenai nilai moral dalam novel Surat Kecil Untuk Tuhan Karya Agnes Davonar. Pada hasil penelitian ini juga dipaparkan tentang penyampaian moral yang digunakan pengarang dalam novel Surat Kecil Untuk Tuhan karya Agnes Davonar dalam kehidupan seharihari.

Moral memiliki peranan penting bagi setiap individu. Dengan adanya moral maka dapat membentuk prilaku individu yang beretika dan sopan santun sesuai dengan chiri khas penduduk negara indonesia. Menurut Nurgiyantoro (2013:441-445), wujud dari penyampaian moral berkaitan dengan hal-hal sebagai berikut ini.

\section{Hubungan manusia dengan diri sendiri}

Menurut

Nurgiyantoro

(2013:324) persoalan manusia dengan dirinya sendiri dapat bermacam-macam jenis dan tingkat intensitasnya, diantaranya sebagai berikut:

1. Bertanggung Jawab Atas Apa Yang Diperbuat

Bertanggung jawab adalah sikap kesadaran yang terdapat dalam diri manusia tentang apa yang telah diperbuat baik perbuatan terpuji maupun tercela sehingga menimbulkan aksi dalam dirinya untuk melakukan kewajiban atas apa yang diperbuat oleh dirinya. Berikut ini kutipan yang termasuk bertanggung jawab atas apa yag diperbuat.

\section{"Teman-temanku sudah berbaris rapi dan aku menyempil diantara mereka. Sebelumnya aku mengucapkan maaf kepada kakak kelas terlebih dahulu" (Davonar, 2015:13)}

Dari kutipan data di atas dapat disimpulkan bahwa keberanian diri untuk bertanggung jawab dan menerima resiko atas perbuatan yang kita lakukan. Dari kutipan di atas menunjukan bahwa Keke berani bertanggung jawab dengan apa yang telah diperbuatnya. Dia mengatakan maaf kepada kakak kelasnya sebab terlambat mengikuti barisan pada saat upacara.

2. Kesanggupan Untuk Menerima Kenyataan Hidup

Apa yang telah ditakdirkan oleh Tuhan baik berupa nikmat ataupun musibah kita harus menerima kenyataan hidup tersebut. Berikut ini kutipan yang termasuk kesanggupan untuk Menerima Kenyataan Hidup.

"Keluarga Kami keluarga yang bahagia, walau ibu dan ayah telah bercerai sejak dua tahun terakhir. Tapi hubungan keduanya masih terjalin dengan baik." (Davonar,2015:2).

"Air mataku mengalir dan rasa sedih mendalam merasuk seluruh ragaku. Sejak lama aku curiga kalau aku bukan terserang tumor dan kini jawaban yang paling menyedihkan telah aku ketahui. Aku bukan terserang tumor, tapi kanker" (Davonar, 2015:77).

Dari kutipan data di atas dapat disimpulkan bahwa Keke menerima takdir yang telah Tuhan berikan kepadanya, seperti menerima perpisahan orang tua yang membuatnya memilih untuk tinggal bersama ayah dan meninggalkan ibunya. Kutipan selanjutnya juga disimpulkan bahwa Keke menerima kenyataan hidup meskipun dirinya terserang penyakit Tumor. Namun Keke terlihat ikhlas menerima kenyataaan tersebut. Semestinya kita juga harus begitu. Karena dibalik musibah yang kita alami tetunya Tuhan akan berikan hikmah dan kebaikan di balik itu semua.

3. Teguh Pada Pendirian

Dalam menjalani hidup teguh pada pendirian merupakan pendirian yang kuat untuk dijadikan sebagai 
pegangan dalam menjalani kehidupan. Seseorang yang teguh pada pendiriannya merupakan orang yang mempunyai pendapat yang tidak dapat berubah-ubah. Berikut kutipan yang menyatakan teguh pada pendirian.

\begin{abstract}
"Aku harus kuat dan aku harus berjuang untuk mereka yang tiada henti mencintai dan ingin aku kembali seperti dulu. Mereka semua menungguku untuk kembali sehat. Aku adalah Keke yang kuat dan selalu berjuang dalam keadaan apapun” (Davonar, 2015:82).

"Aku akan mulai kembali menjadi diriku. Tidak ada lagi air mata yang harus kusimpan, kalaupun ada itu harus kutanam untuk hari kebahagiaan yang siap menungguku” (Davonar, 2015:82).
\end{abstract}

Dari kutipan data di atas dapat disimpulkan bahwa Keke sangat berusaha untuk tetap terlihat baik-baik saja meskipun penyakit yang dihadapinya sangat parah. Keadaan tidak membuat Keke menyerah. Ia memiliki semangat luar biasa dan membuktikan kepada orang orang yang mencintai dirinya untuk kesembuhan atas diri Keke.

\section{Hubungan Manusia dengan Manusia Lain}

Manusia hidup dalam lingkungan sosial yang saling membutuhkan satu sama lain. Menurut Nurgiyantoro (2013:441-445) dalam lingkup sosial dan lingkungan alam. Dalam kehidupan manusia pasti tidak terlepas dengan manusia lain. Di dalam hubungannya dengan manusia lain pasti melibatkan masalah-masalah yang tidak dapat dihindari seperti:

1. Berbuat Baik Terhadap Orang Lain

Sebagai mahkluk sosial yang saling membutuhkan satu sama lain tetntunya kita harus selalu berbuat baik terhadap orang lain. Berikut ini kutipan yang termasuk berbuat baik terhadap orang lain.

"Setelah merasa tenang dan menghapus air mata, aku pun keluar dari toilet dan masih melihat anak kecil bersama ibunya. Kudekati sang ibu lalu aku mulai berusaha berbicara agar tidak dianggap sombong saat lari begitusaja dari mereka tadi" (Davonar, 2015:62).

"Bahkan Angel yang tidak menyukaiku datang untuk memberikan aku semangat"

(Davonar, 2015:96).

Dari kutipan tersebut dapat disimpulkan bahwa dalam keadaan bersedih pun Keke tetap memperlihatkan kepada orang lain bahwa ia baik-baik saja. Ia berusaha berbuat baik dengan menegur sang ibu dan anaknya di sekolahnya meskipun mereka memberikan respon yang kurang baik terhadapnya. Pada kutipan selanjutnya dapat disimpulkan bahwa sosok Angel yang biasanya tidak menyukai Keke turut serta dalam menyemangati Keke.

2. Memiliki Rasa Empati dan Solidaritas Terhadap Orang Lain

Sebagai mahkluk sosial sudah semestinya kita mengerti keadaan orang lain. Rasa empati berarti menganggap apa yang teradi pada diri oranglain seolah-olah juga terjadi kepada diri kita sendiri. Berikut ini kutipan yang termasuk memiliki rasa empati dan solidaritas terhadap orang lain.

"Mataku berkunang- kunang. Tiba-tiba maya mendekati aku sambil berkata. "Ke, Hidung loe mimisan." (Davonar, 2015:35).

"Untungnya teman-temanku langsung menyerahkan berbagai catatan yang tak pernah kucatat." (Davonar, 2015:109-110).

“Aku merasa beruntung karena setiap pergi untuk berobat selalu ditemaniayah dan kedua kakakku" (Davonar, 2015:75). 
Dari kutipan tersebut dapat disimpulkan bahwa keluarga Keke selalu ada dalam keadaan apapun begitu juga dengan teman-temannya yang selalu mendukung dan memberi semangat kepada Keke. Hal ini menunjukan rasa empati dan solidaritas antara mereka sangat tinggi.

3. Tidak memiliki prasangka buruk terhadap orang lain

Setiap mahkluk sosial pasti pernah berprasangka buruk terhadap orang lain. Semestinya kita harus menghindari hal tersebut. Sebab berprasangka buruk terhadap orang lain dapat menyebabkan konflik antar mahkluk sosial tersebut. Berikut ini kutipan yang termasuk tidak memiliki prasangka buruk terhadap orang lain.

"Kecurigaanku mulai timbul
tetapi aku menepis semuanya
mencoba berhuznudjon atau
berprasangka baik. Aku hanya
bisa berdoa kepada Allah semoga
apa yang aku khawatirkan tidak
terjadi." (Davonar, 2015:52).

Dari kutipan data diatas dapat dilihat bahwa Keke tidak memiliki prasangka buruk terhadap orang lain, Keke berusaha menepis semua prasangka buruknya dengan mencoba berprasangka baik, dan berharap apa yang dia takutkan itu tidak terjadi.

\section{Hubungan Manusia dengan Tuhannya} Menurut Nurgiyantoro (2013:441-445) Permasalahan lain yang sering dialami manusia dalam kehidupan adalah permasalahan antara dirinya dengan tuhannya. Permasalahan ini berhubungan dengan aspek ketuhanan misalnya permasalahan yang berkaitan dengan.

1. Percaya terhadap Tuhan

Percaya berarti yakin. Sebagai manusia wajib hukumnya untuk meyakini bahwa Tuhan itu ada. Berikut ini kutipan yang termasuk percaya terhadap Tuhan.

\begin{abstract}
"Ya, Tuhan... Aku bukan terserang tumor, tapi kanker... Mengapa aku mengalami penyakit seperti ini" (Davenor, 2015:77).

"ini mukjizat Tuhan, Keke.

Tuhan saying pada Keke" (Davenor, 2015:103).

"Ya, Tuhan... Aku tak ingin menyusahkan ayah lagi. Jangan lagi engkau memberikan cobaan ini kepada ayah yang sangat kucintai" (Davenor, 2015:126).
\end{abstract}

Dari kutipan data di atas dapat disimpulkan bahwa Keke percaya terhadap Tuhan. Segala yang telah direncanakan Tuhan pasti akan membawa hikmah untuk kedepannya.

2. Bersyukur kepada Tuhannya

Sebagai Mahkluk ciptaan-Nya kita harus bersyukur asat nikmat yang dikaruniai kepada kita. Rasa syukur terkadang muncul seperti kelegaan dalam hati seseorang. Berikut ini kutipan yang menjunjukan rasa bersyukur kepada Tuhan.

"Aku patut bersyukur karena
proses kemotrapi kedua dan
ketiga tidak seperti proses pertama
yang begitu menyakitkan"
(Davenor, 2015:159).
"Aku bersyukur karena semua
sahabatku dikelas tidak pernah
merasa terganggu oleh
keadaanku” (Davenor, 2015:200).

Dari kutipan data di atas dapat disimpulkan bahwa Keke selalu bersyukur kepada Tuhan atas nikmat yang telah dikaruniakan kepada dirinya. Meskipun Tuhan sedang memberi cobaan kepada dirinya, tetap saja ia tidak lupa untuk bersyukur kepada Tuhan. Untuk bersyukur tidak hanya tentang kebahagiaan yang diberikan Tuhan kepada kita. Ketika sedaang diberi cobaan atau musibah kepada kita, hendaknya kita tetap harus selalu bersyukur. 
3. Menjalankan PerintahNya dan Menjauhi LaranganNya

"Karena tidak bisa juga
tenang, ia mengambil kitab suci
Al-Qur'an yang telah ia siapkan
disamping meja tidurku"
(Davenor, 2015:154).
"Tuhan, besarkanlah hati
orang-orang di sekitarku untuk
ikhlas menerima keadaanku"
(Davenor, 2015:166).

Dari kutipan data di atas dapat disimpulkan bahwa Keluarga Keke menjalankan perintahNya dan begitu juga dengan Keke yang selalu mengingat dan menyerahkan diri kepada Tuhan dengan cara selalu berdoa dalam keadaan apapun.

\section{SIMPULAN}

Berdasarkan hasil penelitian yang dipaparkan pada bab sebelumnya dapat disimpulkan bahwa Novel Surat Kecil Untuk Tuhan karya Agnes Devanor diterbitkan pertama kali pada tahun 2008 namun dicetak kembali pada tahun 2015. Novel ini menceritakan perjuangan hidup seorang anak gadis remaja yang menderita penyakit kanker jaringan lunak pertama di Indonesia.

Novel Surat Kecil Untuk Tuhan karya Agnes Devanor ini memiliki banyak wujud nilai moral yang bisa yang dapat dijadikan sebagai contoh kepada penikmat karya sastra dalam bertingkah laku di kehidupannya sehari-hari.

Peneliti berharap semoga dengan adanya penelitian ini terbentuklah penikmat sastra dan juga generasi penerus yang memiliki nilai moral.

\section{DAFTAR PUSTAKA}

Abraham, Ihsan. Struktur Kepribadian Tokoh Dalam Novel Surat Kecil Untuk Tuhan Karya Agnes Davonar. KEMBARA: Jurnal Keilmuan Bahasa, Sastra dan Pengajarannya Volume 3, Nomor 1, April 2017. Tersedia: http://ejournal.umm.ac.id/index.p $\mathrm{hp} /$ kembara/article/view/4378

Anisah, Zulfatun. Realitas Kehidupan Islami dalam Novel Surat Kecil untuk Tuhan Karya Agnes Davonar (Kajian Mimetik). ISTAWA: Jurnal Pendidikan Islam Volume 3, Nomor 1, Januari-Juni 2018. Tersedia: http://journal.umpo.ac.id/index.p hp/istawa/article/view/1000/727

Budiningsih, Asri.2004. Pembelajaran Moral Berpijak pada Karakteristik Siswa dan Budidaya. Jakarta: PT. Rineka Cipta.

Davonar, Agnes. 2015. Surat Kecil Untuk Tuhan. Depok. Novelas.

Mirnawati, Akhmad Murtadlo, dan Syamsul Rijal. Analisis Novel Aurat Kecil Untuk Tuhan Karya Agnes Devanor Ditinjau dari Sosiologi Sastra. Jurnal Ilmu Budaya Vol. 3, No. 3, Juli 2019. Tersedia: http://ejournals.unmul.ac.id/index.php/J BSSB/arti cle/view/1998.

Nasution, Adelya Ramadani. Pesan Moral dalam Novel Surat Kecil untuk Tuhan Karya Agnes Davonar Tinjauan Sosiologi Sastra. Universitas Sumatera Utara Repositori Institusi USU. 2019. Tersedia: http://repositori.usu.ac.id/handle/ $123456789 / 12963$.

Nurgiyantoro, Burhan. 2013. Teori Pengkajian Fiksi. Yogyakarta: UGM Press.

Rosyanti, Sinta. Nilai Moral Dalam Novel surat Kecil Untuk Tuhan Karya Agnes Devanor. Jurnal Diksatrasia vol 1 nomor 2, Agustus 2017.Tersedia: https://jurnal.unigal.ac.id/index.p hp/diksatrasia/article/view/597.

Sugiyono, 2009, Metode Penelitian Kuantitatif, Kualitatif dan R\&D, Bandung: Alfabeta. 